\title{
A família Rubiaceae na Reserva Biológica Guaribas, Paraíba, Brasil. Subfamília Rubioideae ${ }^{1}$
}

\author{
Maria do Socorro Pereira ${ }^{2,3,4}$ e Maria Regina de Vasconcellos Barbosa ${ }^{3}$
}

Recebido em 19/08/2004. Aceito em 7/11/2005

\begin{abstract}
RESUMO - (A família Rubiaceae na Reserva Biológica Guaribas, Paraíba, Brasil. Subfamília Rubioideae). Este trabalho consiste no levantamento dos representantes de Rubiaceae subfamília Rubioideae na Reserva Biológica Guaribas, Estado da Paraíba, Brasil. Foram realizadas coletas intensivas no período de outubro/2000 a outubro/2001, as quais resultaram em 17 espécies e nove gêneros de Rubioideae. Os gêneros com maior número de espécies foram Psychotria L. (seis) e Borreria G. Mey. (quatro). Coccocypselum P. Browne, Declieuxia Kunth, Diodia L., Mitracarpus Zucc. ex Roem. \& Schult., Palicourea Aubl., Richardia L. e Staelia Cham. \& Schltdl. apresentaram uma única espécie cada. Perama hirsuta Aubl., de posição taxonômica incerta na família, também foi tratada neste trabalho. São apresentados chave, descrições, comentários e ilustrações dos táxons.
\end{abstract}

Palavras-chave: Rubiaceae, Rubioideae, Mata Atlântica, taxonomia

\begin{abstract}
The family Rubiaceae in the Guaribas Biological Reserve, Paraíba State, Brazil. Subfamily Rubioideae). This paper describes the results of a survey of the Rubiaceae subfamily Rubioideae in the Guaribas Biological Reserve, State of Paraíba, Brazil. Intensive collections were made from October/2000 to October/2001, revealing 17 species and nine genera of Rubioideae. The most diverse genera were Psychotria L. (six species) and Borreria G. Mey. (four species). Coccocypselum P. Browne, Declieuxia Kunth, Diodia L., Mitracarpus Zucc. ex Roem. \& Schult., Palicourea Aubl., Richardia L. and Staelia Cham. \& Schltdl. were each represented by a single species. Perama hirsuta Aubl., of uncertain position within the family, is also treated in this paper. A key, descriptions, notes, and illustrations of the taxa are provided.
\end{abstract}

Key words: Rubiaceae, Rubioideae, Atlantic Forest, taxonomy

\section{Introdução}

Rubiaceae sensu Robbrecht (1988) está dividida em quatro subfamílias: Antirheoideae, Rubioideae, Cinchonoideae e Ixoroideae. Todavia, estudos filogenéticos recentes sugerem a sustentação de apenas três subfamílias, Rubioideae, Cinchonoideae e Ixoroideae (Rova et al. 2002).

Estudos com a família foram realizados por Smith \& Downs (1956), Sucre (1959; 1960/1961; 1971), Porto et al. (1977), Dillenburg \& Porto (1985), Figueiredo et al. (1990), Johansson (1992), Taylor \& Lorence (1992), Burger \& Jiménez (1994), Jung-Mendaçolli (1994), Andersson \& Rova (1999), Taylor (1994a; b; c; 1997; 2000). Classificações infragenéricas e publicações de novos táxons também foram propostas por Bacigalupo \& Cabral (1996; 1998; 1999a; b), Cabral
(1996; 1999), Cabral \& Bacigalupo (1996; 1999; 2000a; b), Delprete (2001) e Souza \& Sales $(2001 ; 2004)$.

Recentemente, foi proposta por Bremer \& Manen (2000) uma nova delimitação para a subfamília Rubioideae, ficando esta constituída por 153 gêneros e 16 tribos. Dessas últimas, doze correspondem mais ou menos à circunscrição anterior, Ophiorrhizeae e Coussareeae apresentam circunscrição muito diferente, e Lasiantheae e Danaideae são novas tribos. Para o Brasil, são estimados 38 gêneros de Rubioideae (Barroso et al. 1986).

As espécies de Rubioideae têm ampla distribuição, principalmente nas regiões tropicais e subtropicais. São plantas lenhosas ou herbáceas, com estípulas inteiras ou divididas, freqüentemente bífidas ou fimbriadas, ovário com um ou muitos óvulos por lóculo, e frutos carnosos ou secos. A subfamília é caracterizada pela

\footnotetext{
Parte da Dissertação de Mestrado da primeira Autora

2 Programa de Pós-Graduação em Biologia Vegetal (PPGBV), Universidade Federal de Pernambuco (UFPE)

3 Universidade Federal da Paraíba, Departamento de Sistemática e Ecologia, Centro de Ciências Exatas e da Natureza, C. Postal 5065, CEP 58051-970, João Pessoa, PB, Brasil

4 Autor para correspondência: m.s_pereira@bol.com.br
} 
presença generalizada de ráfides e deiscência valvar da corola. O gênero de maior diversidade na subfamília é Psychotria L., com aproximadamente 1.650 espécies (Hamilton 1989).

O objetivo deste trabalho foi realizar o levantamento da subfamília Rubioideae na Reserva Biológica Guaribas, contribuindo para o conhecimento da família Rubiaceae no Estado da Paraíba, e também subsidiar estudos taxonômicos com grupos específicos.

\section{Material e métodos}

A Reserva Biológica Guaribas (REBIO Guaribas) está localizada nos municípios de Mamanguape e Rio Tinto, a 6 $44^{\prime} 02$ "S 35 $35^{\circ} 10^{\prime} 32$ "W e 6 40 '53"S 3509'59'W, litoral norte do Estado da Paraíba, a $70 \mathrm{~km}$ da capital João Pessoa. Possui 4.321 ha, separados em três áreas: área I (616 ha), área II (3.378 ha) e área III (327 ha). A vegetação local é constituída por remanescentes de Mata Atlântica e manchas de Cerrado, denominados, na região, de tabuleiros (Pereira \& Barbosa 2004).

Foram realizadas coletas mensais, de forma casual, buscando abranger todas as áreas da Reserva, no período de outubro/2000 a outubro/2001. O material coletado está depositado no herbário Lauro Pires Xavier (JPB) com duplicatas no herbário Geraldo Mariz (UFP).

Foi adotada a classificação de Bremer \& Manen (2000) para a subfamília Rubioideae. A terminologia para caracterização das folhas foi baseada em Rizzini (1977), e frutos e sementes seguem Barroso et al. (1999). As dimensões das flores heterostílicas representam toda a variação encontrada na espécie, sem distinção entre brevistilas e longistilas. As abreviaturas dos nomes de autores estão de acordo com Brummitt \& Powell (1992).

A identificação do material foi realizada a partir de análise morfológica detalhada, com o auxílio de chaves analíticas, descrições e diagnoses encontradas na literatura especializada e, quando possível, através da análise de exemplares-tipo, ou fotografias dos mesmos. Foram consultados materiais dos herbários ALCB, CEPEC, EAN, IPA, JPB e PEUFR (siglas de acordo com Holmgren et al. 1990).

A chave para separação das espécies, as descrições e as ilustrações foram elaboradas com base apenas no material proveniente da Reserva Biológica Guaribas.

\section{Resultados e discussão}

Foram encontradas, na Reserva Biológica Guaribas, 17 espécies pertencentes a nove gêneros de Rubioideae, sendo Psychotria o gênero com o maior número de espécies (seis), seguido de Borreria G.Mey. (quatro). Os demais, Coccocypselum P. Browne, Declieuxia Kunth, Diodia L., Mitracarpus Zucc. ex Roem. \& Schult., Palicourea Aubl., Richardia L., e Staelia Cham. \& Schltdl., apresentaram uma única espécie cada. Além destes, também foi registrada a ocorrência do gênero Perama Aubl., com uma única espécie, $P$. hirsuta Aubl., integrante da tribo Perameae, cuja posição taxonômica ainda é incerta na família Rubiaceae (Robbrecht 1988; Manen 2000). A maioria dos autores tratava o gênero Perama na tribo Spermacoceae, por considerar que este apresenta características comuns ao grupo, como hábito herbáceo, ovário com um óvulo por lóculo fixado no meio do septo, e frutos deiscentes (Schumann 1888; Verdcourt 1958; Steyermark 1974). Robbrecht (1988) e Bremer \& Manen (2000) incluem Perama na tribo Perameae e a consideram com posição ainda incerta na família. Adotamos a mesma posição destes últimos autores, e não incluímos a tribo Perameae em nenhuma das subfamílias de Rubiaceae, sendo dessa forma, P. hirsuta tratada à parte neste trabalho.

Subfamília Rubioideae

Plantas lenhosas ou herbáceas; estípulas inteiras ou divididas, freqüentemente bipartidas, bífidas ou fimbriadas; flores andróginas, em geral heterostílicas, corola com lobos valvares, raramente imbricados ou contortos; um a muitos óvulos por lóculo, raramente dois; frutos secos ou carnosos, drupáceos ou bacáceos.

Chave para os táxons de Rubiaceae-Rubioideae encontrados na Reserva Biológica Guaribas

1. Estípulas livres, não formando bainha estipular, bipartidas, bífidas, ou raramente inteiras, unidentadas

2. Ervas prostradas; ovário pluriovulado 5. Coccocypselum hirsutum

2. Ervas eretas, subarbustos, arbustos ou arvoretas; ovário uniovulado 
3. Estípulas bipartidas ou bífidas; frutos carnosos

4. Corola amarela, de base gibosa

9. Palicourea crocea

4. Corola branca ou roxa, de base não gibosa

5. Inflorescências com brácteas conspícuas, involucrais; frutos azuis, roxos ou negros

6. Lâmina foliar com mais de $14 \mathrm{~cm}$ compr.; flores com corola roxa

12. Psychotria bracteocardia

6. Lâmina foliar até $14 \mathrm{~cm}$ compr.; flores com corola branca

7. Arbustos com 0,6-2 m alt.; pedúnculo da inflorescência ereto quando jovem; 12-15 brácteas lineares a estreito-oblongas

11. Psychotria barbiflora

7. Subarbustos com 30-60 cm alt.; pedúnculo da inflorescência pêndulo quando jovem; 4 brácteas ovadas a estreito-ovadas 14. Psychotria hoffmannseggiana

5. Inflorescências com brácteas inconspícuas, não involucrais; frutos brancos

10. Psychotria bahiensis

3. Estípulas inteiras; frutos carnosos ou secos

8. Frutos carnosos, drupáceos

9. Lâmina foliar 15-26×6-11 cm; inflorescência multiflora, pedúnculo longo, $7-13 \times 0,3-0,4 \mathrm{~cm}$ 13. Psychotria carthagenensis

9. Lâmina foliar 2-4×1-1,5 cm; inflorescência pauciflora, pedúnculo curto, $2-3 \times 1-2 \mathrm{~mm}$ 15. Psychotria subtriflora

8. Frutos secos, esquizocarpos ou cápsulas

10. Esquizocarpo; corola azul a roxa; ovário bilocular.

6. Declieuxia fruticosa

10. Cápsula; corola amarela; ovário trilocular 18. Perama hirsuta*

1. Estípulas unidas, formando uma bainha estipular apicalmente fimbriada

11. Esquizocarpos

12. Ovário trilocular, estilete trífido; esquizocarpos com três mericarpos

16. Richardia grandiflora

12. Ovário bilocular, estilete bífido a bilobado; esquizocarpos com dois mericarpos

13. Um ou dois mericarpos deiscentes

14. Um mericarpo indeiscente e o outro se abrindo apenas na base

2. Borreria ocymifolia

14. Dois mericarpos abrindo-se do ápice até a região mediana, ou totalmente deiscentes 3. Borreria scabiosoides

13. Dois mericarpos indeiscentes 7. Diodia apiculata

11. Cápsulas

15. Cápsulas septicidas, com deiscência longitudinal

16. Ervas prostradas, folhas opostas, ovadas; flores em glomérulos capituliformes exclusivamente terminais 1. Borreria humifusa

16. Ervas eretas, folhas verticiladas, lanceoladas ou lineares; flores em glomérulos não capituliformes, axilares e terminais

4. Borreria verticillata

15. Cápsulas não septicidas, com deiscência circuncisa, transversal ou transverso-oblíqua

17. Cálice com dois lacínios iguais, frutos com deiscência transverso-oblíqua ..... 17. Staelia virgata

17. Cálice com quatro lacínios desiguais, dois a dois, frutos com deiscência circuncisa, transversal

8. Mitracarpus frigidus var. discolor

*Posição taxonômica incerta na família Rubiaceae

1. Borreria humifusa Mart., Flora 24: 68. 1841.

Fig. 1-4

Erva prostrada, formando estolões. Ramos pubérulos a escabros. Estípulas 2-4×1-3 mm, unidas, fimbriadas, glabras, com 4-6 lacínios não glandulares formando uma bainha. Folhas opostas. Lâmina foliar
1,5-2,5×1,5-2 cm, ovada, base arredondada, ápice agudo, margem revoluta, membranácea, glabrescente em ambas as faces, 3-4 pares de nervuras secundárias; pecíolo 0,5-1×0,1-0,2 cm, glabro. Glomérulos capituliformes terminais, 3-5×5-7 mm, sésseis, (10-)1520(-35) flores; 2-4 brácteas involucrais, foliáceas, 4-6×3-4 mm, ovadas, verdes, glabras, 2 bractéolas florais, 1-2×1-1,5 mm, inconspícuas, translúcidas, 
glabras. Flores sésseis, botões florais oblongos, ápice agudo a obtuso. Cálice subulado, 4-laciniado, 1-3×1-2 mm, pubérulo a escabro, lacínios iguais entre si. Corola infundibuliforme, branca, tetrâmera, tubo 1-2×2-2,5 mm, glabro externamente, internamente com um anel de tricomas no ponto de inserção dos estames, lobos 1-2×2-3 mm, triangulares, pilosos no ápice. Estames 4, exsertos, presos na fauce; filetes 1-2 mm compr. Hipanto não muricado. Ovário bilocular, uniovulado, óvulos presos ao septo; estilete exserto, 3-5 mm compr., glabro; estigma bilobado. Cápsula septicida, 1-1,2×0,5-1 mm, oblonga ou obovada, deiscência longitudinal do ápice até a porção mediana, glabra a escabra. Sementes 0,5-1×0,2-0,5 mm, elípticas, com um sulco longitudinal.

Material selecionado: BRASIL. Paraíba: Mamanguape, Área II, 31/V/2001, fl. fr., Pereira 481 (JPB).

Borreria humifusa tem distribuição neotropical (Andersson 1992; Bacigalupo \& Cabral 1996). No Brasil, há registros para a Região Nordeste (Schumann 1889; Barbosa et al. 1996). Caracteriza-se pelo hábito prostrado, pela disposição terminal das inflorescências e forma ovada das folhas, sendo encontrada em ambientes bastantes úmidos, formando estolões e verdadeiros tapetes no interior da mata. Na REBIO foi coletada às margens de riachos e córregos no interior da mata, sendo considerada uma espécie palustre. Encontrada com flores e frutos de abril a setembro.

2. Borreria ocymifolia (Roem. \& Schult.) Bacigalupo \& E.L.Cabral, Opera Bot. Belg. 7: 297. 1996.

Fig. 5-7

Erva ereta, 30-40 cm alt. Ramos híspidos. Estípulas 4-5×3-6 mm, unidas, fimbriadas, hirsutas a híspidas, com 6-8 lacínios glandulares formando uma bainha. Folhas opostas. Lâmina foliar 7-9,5×2-2,7 cm, lanceolada, base atenuada, ápice agudo, margem inteira, membranácea, face superior pubérula a escabra, face inferior escabra a híspida, 7-8 pares de nervuras secundárias; pecíolo 0,5-1×0,1-0,2 $\mathrm{cm}$, híspido. Glomérulos não capituliformes axilares, raramente terminais, 3-7×5-9 mm, sésseis, (10-)15-25(-35) flores; 2 brácteas não involucrais, foliáceas, $6-9 \times 1-2 \mathrm{~cm}$, elípticas, verdes, escabras, 2 bractéolas florais, 1,5-2×1-2 mm, inconspícuas, branco-esverdeadas, glabras. Flores sésseis, botões florais oblongos, ápice agudo a obtuso. Cálice subulado, 4-laciniado, 1-2×1,5-2 mm, híspido, lacínios iguais entre si. Corola hipocrateriforme, branca, tetrâmera, tubo
2-4×1-1,5 mm, glabro externamente, internamente com um anel de tricomas no terço superior, lobos 2-3×1-2 mm, oblongos, pilosos no ápice. Estames 4, exsertos, presos na fauce; filetes 1-2 mm compr. Hipanto não muricado. Ovário bilocular, uniovulado, óvulos presos ao septo; estilete exserto, 4-5 mm compr., glabro; estigma bilobado. Esquizocarpo 2-4×1,5-2 mm, elíptico, oblongo ou linear-oblongo, separando-se em dois mericarpos, um deles indeiscente e o outro deiscente apenas na base, híspido a escabro. Sementes 1,5-2,5×0,3-0,6 mm, elípticas ou oblongas, com um sulco longitudinal.

Material selecionado: BRASIL. Paraíba: Mamanguape, Área II, 31/V/2001, fl. fr., Pereira 445 (JPB).

Borreria ocymifolia tem distribuição neotropical (Andersson 1992; Lorence 1999). No Brasil, ocorre em várias regiões. Na REBIO, foi coletada em lugares sombreados, no interior da mata. Floresce de fevereiro a maio e frutifica de março a outubro.

3. Borreria scabiosoides Cham. \& Schltdl., Linnaea 3: 318.1828 .

Erva ereta, 80-90 cm alt., ramificada. Ramos glabros. Estípulas 4-6×4-5 mm, unidas, fimbriadas, glabras, com 6-8 lacínios não glandulares formando uma bainha. Folhas opostas. Lâmina foliar 7-12×1-2,5 cm, lanceolada, base atenuada, ápice agudo, membranácea, escabra a híspida em ambas as faces, 3-4 pares de nervuras secundárias, pecíolo 0,5-1×0,1-0,2 cm, escabro. Glomérulos não capituliformes terminais e axilares, 0,7-1,2×0,8-1,6 cm, sésseis, (65-)100-200(-250) flores; 2 brácteas não involucrais, foliáceas, $5-7 \times 0,5-1 \mathrm{~cm}$, linear-lanceoladas, verdes, escabras, 2 bractéolas florais, 1-2×0,5-1 mm, lineares, branco-esverdeadas, glabras. Flores sésseis, botões florais oblongos, ápice obtuso. Cálice subulado, 4-laciniado, 2-4×1-2 mm, pubérulo a escabro, lacínios iguais entre si. Corola infundibuliforme, branca, tetrâmera, tubo 3-4×1-2 mm, glabro externamente, internamente com um anel de tricomas na porção mediana, lobos 1-2×0,5-1 mm, triangulares, pubérulos no ápice. Estames 4, exsertos, presos na fauce; filetes 1,5-2 mm compr. Hipanto não muricado. Ovário bilocular, uniovulado, óvulos presos ao septo; estilete exserto, 4-6 mm compr., glabro; estigma bilobado. Esquizocarpo 2,5-4×1,5-2 mm, oblongo ou obovado, separando-se em dois mericarpos deiscentes, do ápice até a região mediana ou totalmente, pubérulo a escabro. Sementes 1,3-2×0,3-0,5 mm, elípticas ou oblongas, com um sulco longitudinal. 
Material selecionado: BRASIL. Paraíba: Mamanguape, Área I, 5/X/2001, fl. fr., Pereira 604 (JPB).

Borreria scabiosoides tem distribuição neotropical (Andersson 1992; Lorence 1999). No Brasil, ocorre em vários ambientes, desde os mais úmidos, como a Mata Atlântica e a Floresta Amazônica, até os mais secos, como Caatinga e Cerrado. Em Guaribas, ocorre nas áreas mais abertas e ensolaradas, com uma vegetação arbustivoherbácea, ou ainda nas áreas de tabuleiros, onde o solo é arenoso. Floresce de junho a outubro e frutifica de agosto a outubro.

4. Borreria verticillata (L.) G. Mey., Prim. Fl. Esseq. 83. 1818.

Erva ereta, 40-50 cm alt., ramificada. Ramos glabros. Estípulas 5-7×3-4 mm, unidas, fimbriadas, pubérulas a escabras, com 6-9 lacínios não glandulares formando uma bainha. Folhas verticiladas. Lâmina foliar 2-3,5×0,4-1 cm, linear a lanceolada, base atenuada, ápice agudo, margem revoluta, membranácea, glabra, híspida a escabra em ambas as faces, 2-4 pares de nervuras secundárias; pecíolo 1-4×1-2 mm, glabro. Glomérulos não capituliformes terminais e axilares, 0,6-1,2×0,7-1,2 cm, sésseis, (80-)120-200(-240) flores; 2-4 brácteas não involucrais, foliáceas, 1,5-2,5×0,5-0,8 cm, lineares a lanceoladas, verdes, pubérulas a escabras, 2 bractéolas florais, 1-2×0,5-1 mm, inconspícuas, translúcidas, glabras. Flores sésseis, botões florais oblongos, ápice obtuso. Cálice subulado, 2-laciniado, 1-3×1-2 mm, glabro, lacínios iguais entre si. Corola infundibuliforme, branca, tetrâmera, tubo 1-2×1-1, $5 \mathrm{~mm}$, glabro externamente, internamente com um anel de tricomas no ponto de inserção dos estames, lobos 1-3×1-1,5 mm, triangulares, glabros. Estames 4, exsertos, presos na fauce; filetes 1-1,5 mm compr. Hipanto não muricado. Ovário bilocular, uniovulado, óvulos presos ao septo; estilete exserto, 3-5 mm compr., glabro; estigma bífido. Cápsula septicida, 1,5-2×0,2-0,8 mm, linear-oblonga ou oblonga, deiscência longitudinal até a região mediana, glabra. Sementes 0,5-1×0,2-0,5 mm, linear-oblongas ou elípticas, com um sulco longitudinal.

Material selecionado: BRASIL. Paraíba: Rio Tinto, Área III, 30/VIII/2001, fl. fr., Pereira 563 (JPB).

Borreria verticillata tem distribuição neotropical (Andersson 1992), sendo encontrada no México e nas Américas Central e do Sul (Schumann 1888; Steyermark 1974; Lorence 1999). Caracteriza-se pelo hábito, disposição e forma das folhas e inflorescências.
Em Guaribas, é freqüente em lugares secos e abertos, com solo arenoso, ou ainda na borda da mata. Floresce de abril a outubro e frutifica de maio a agosto, e em outubro.

5. Coccocypselum hirsutum Bartl. ex DC., Prodr. 4: 396. 1830.

Fig. 8

Erva prostrada. Ramos hirsutos. Estípulas 4-5×1-2 mm, livres, inteiras, unidentadas, lineares, hirsutas. Folhas opostas. Lâmina foliar 4-7×3-4 cm, ovada a lanceolado-ovada, base arredondada, ápice agudo, membranácea, hirsuta a velutina em ambas as faces, 5-7 pares de nervuras secundárias; pecíolo 1-3,5×0,1-0,2 cm, hirsuto. Glomérulos subcapitados paucifloros, terminais e axilares, $3-5 \times 0,5-1 \mathrm{~cm}$, pedunculados, (3-)5-7(-9) flores; 2 brácteas não involucrais, 5-6×2-3 mm, lineares, verdes, hirsutas, 1-2 bractéolas florais, 2-3×1-2 mm, lineares, verdes, hirsutas; pedúnculo 1,5-4×0,1-0,2 cm, verde, hirsuto. Flores sésseis, botões florais oblongos, ápice agudo. Cálice subulado, 4-laciniado, 3-4×1-2 mm, hirsuto, lacínios iguais entre si. Corola infundibuliforme, azul, tetrâmera, tubo 3-4×2-3 mm, hirsuto externamente, internamente com um anel de tricomas no terço inferior, lobos 2-3×1-2 mm, triangulares, hirsutos externamente e glabros internamente. Estames 4, exsertos, presos na fauce; filetes 1-2 mm compr. Hipanto não muricado. Ovário bilocular, pluriovulado, óvulos de inserção axial; estilete exserto, 7-8 mm compr., glabro; estigma bífido. Baga 0,9-1,4×0,5-0,8 cm, oblongo-ovada ou oblongoelíptica, com estrias longitudinais, azul, hirsuta. Sementes 1-1,5×1-1,5 mm, subpiramidais numa face e ligeiramente planas na outra, muricadas do centro para as extremidades.

Material selecionado: BRASIL. Paraíba: Mamanguape, Área II, 23/II/2001, fl., Pereira 264 (JPB).

Coccocypselum hirsutum tem distribuição neotropical (Andersson 1992; Lorence 1999), sendo encontrada em várias regiões do Brasil (Barbosa et al. 1996; Jung-Mendaçolli 1999). Destaca-se das demais espécies estudadas pela coloração azul das flores e frutos, e por apresentar ovário pluriovulado. É uma erva delicada, ocorrendo apenas em ambientes bastante úmidos e com grande quantidade de liteira acumulada. Na REBIO Guaribas, foi encontrada em lugares sombreados e ao longo das margens de riachos e córregos, no interior da mata. Floresce de fevereiro a março e de julho a outubro, e frutifica de março a julho. 


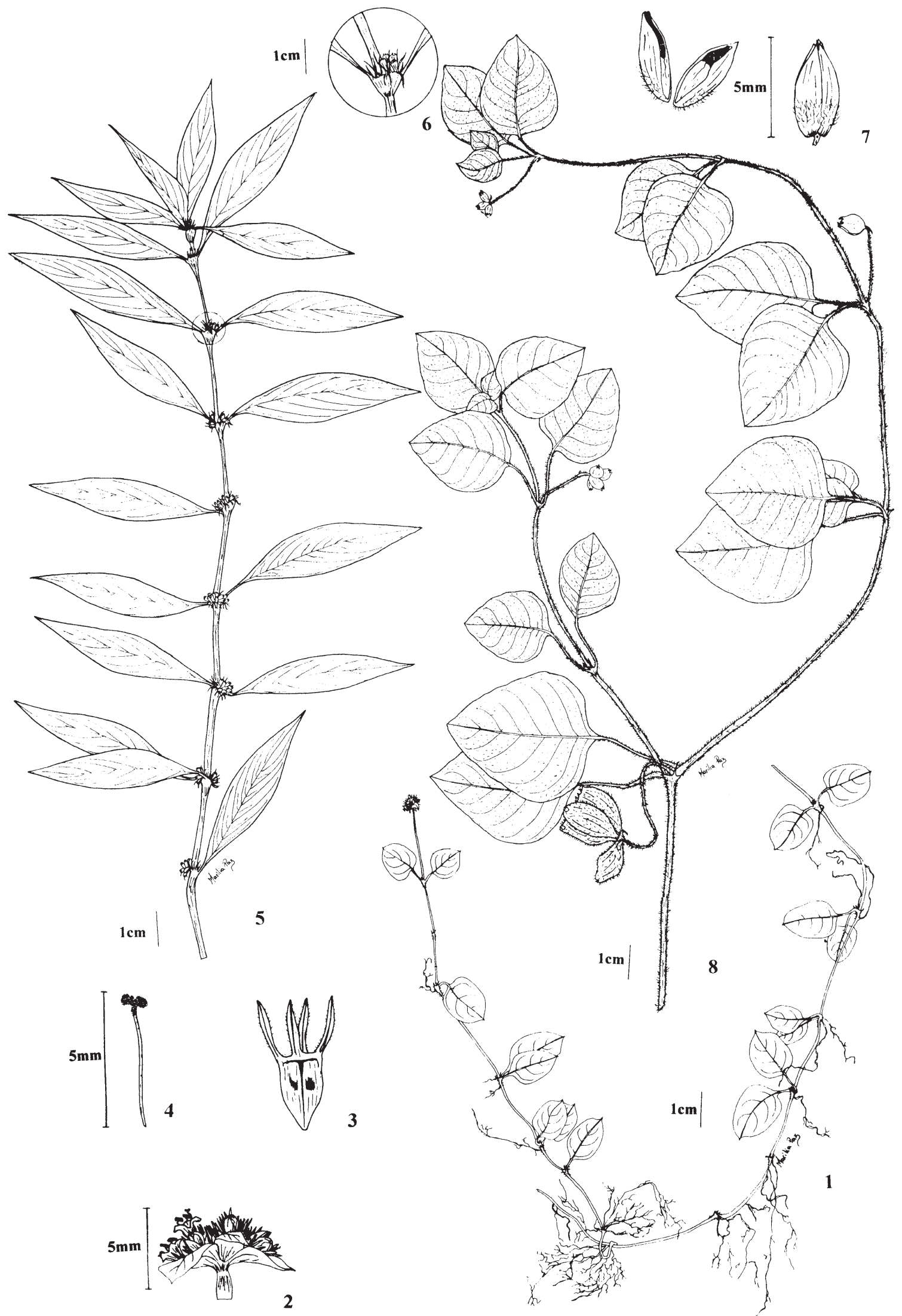

Figuras 1-8. Borreria humifusa Mart. 1. Hábito. 2. Glomérulo capituliforme. 3. Cálice e ovário. 4. Estilete e estigma (Pereira 481). Borreria ocymifolia (Roem. \& Schult.) Bacigalupo \& E.L. Cabral. 5. Ramo frutificado. 6. Estípula. 7. Fruto (Pereira 292). Coccocypselum hirsutum Bartl. ex DC. 8. Ramo frutificado (Pereira 443). 
6. Declieuxia fruticosa (Willd. ex Roem. \& Schult.) Kuntze, Revis. Gen. Pl. 1: 279. 1891.

Arbusto a subarbusto, 0,4-1,5 m alt., ramificado. Ramos glabros. Estípulas 1-3×0,5-1 mm, livres, inteiras, unidentadas, lineares, glabras. Folhas opostas. Lâmina foliar 2,5-4×1-2 cm, lanceolada, base atenuada, ápice agudo, margem revoluta, membranácea a cartácea, glabra em ambas as faces, 4-6 pares de nervuras secundárias; pecíolo 1-2×0,2-0,5 mm, glabro. Dicásios compostos terminais, $2,5-8 \times 1,5-3,5 \mathrm{~cm}$, pedunculados, (13-)20-25(-39) flores; 2 brácteas não involucrais, 6-8×1-2 mm, lineares a oblongas, verdes, glabras, 1-2 bractéolas florais, $1-2 \times 0,3-0,5 \mathrm{~mm}$, lineares a oblongas, verdes, glabras; pedúnculo 2-5,5×0,1-0,2 cm, verde, glabro. Flores com pedicelo $1-2 \times 0,5-1 \mathrm{~mm}$, glabro; botões florais oblongos, ápice agudo a obtuso. Cálice subulado, 4-laciniado, 1-1,5×0,5-1 mm, glabro, lacínios iguais entre si. Corola tubulosa, azul a roxa, tetrâmera, tubo 4-5×1-2 mm, glabro externamente, piloso internamente, da porção mediana até a fauce, lobos 1-1,5×0,5-1 mm, triangulares, glabros. Estames 4, inclusos, fixos na porção mediana do tubo; filetes 0,2-0,5 mm compr. Hipanto não muricado. Ovário bilocular, uniovulado, óvulos de inserção basal; estilete exserto, 5-6,5 mm compr., glabro; estigma bífido. Esquizocarpo dicoca, $2-3 \times 2-4 \mathrm{~mm}$, azul a preto, glabro. Sementes 2-3×2-4 mm, planas, circulares, com estrias circulares.

Material selecionado: BRASIL. Paraíba: Mamanguape, Área I, 18/VIII/1988, fl., Félix \& Miranda 28 (JPB).

Declieuxia fruticosa tem distribuição neotropical (Kirkbride 1976). No Brasil, ocorre nos Estados do Amapá, Bahia, Ceará, Distrito Federal, Goiás, Maranhão, Mato Grosso, Minas Gerais, Pará, Paraíba, Paraná, Pernambuco, Rio de Janeiro, Roraima, Santa Catarina e São Paulo (Steyermark 1974; Kirkbride 1976; Lorence 1999). Na REBIO Guaribas, foi encontrada nas áreas de tabuleiro, com flores de agosto a novembro e frutos de outubro a janeiro.

7. Diodia apiculata (Willd. ex Roem. \& Schult.) K.Schum., Bot. Jahrb. Syst. 10: 313. 1889.

Fig. 9-15

Erva ereta, 20-60 cm alt., ramificada. Ramos hirsutos. Estípulas 4-6×3-4 mm, unidas, fimbriadas, hirsutas, com 8-12 lacínios não glandulares formando uma bainha. Folhas opostas. Lâmina foliar 2,5-5×0,3-0,6 cm, linear-lanceolada, base atenuada, ápice acuminado, margem revoluta, membranácea, face superior escabra, face inferior glabra, pubérula a escabra, 2-4 pares de nervuras secundárias; pecíolo ausente. Glomérulos não capituliformes axilares, raramente terminais, 0,5-0,9×4-6 mm, sésseis, (1-)2-4(-5) flores; 2 brácteas não involucrais, foliáceas, 1-3,5×0,2-0,6 cm, lineares, verdes, glabras, 2 bractéolas florais, 1-2×1-1,2 mm, inconspícuas, verdes, glabras. Flores sésseis, botões florais oblongos, ápice agudo. Cálice subulado, 4-laciniado, 3-4×1-2 mm, pubérulo a escabro, lacínios iguais entre si. Corola infundibuliforme, lilás, tetrâmera, tubo $4-7 \times 2-4 \mathrm{~mm}$, pubérulo externamente, internamente com um anel de tricomas na base, lobos 1-3×2-3 mm, triangulares, pilosos no ápice. Estames 4 , exsertos, presos na fauce ou na porção mediana do tubo; filetes 1-2 mm compr. Hipanto não muricado. Ovário bilocular, uniovulado, óvulos presos ao septo; estilete exserto, 5-9 mm compr., glabro; estigma bilobado a bífido. Esquizocarpo 2,5-3 $\times 2-3,5 \mathrm{~mm}$, obovado, costado, com sulcos longitudinais, separando-se em dois mericarpos indeiscentes, pubérulo a híspido. Sementes, 1,5-2×1,2-1,5 mm, plano-convexas, elípticas ou obovadas, com estrias longitudinais.

Material selecionado: BRASIL. Paraíba: Mamanguape, Área I, 27/IV/2001, fl. fr., Pereira 366 (JPB).

Diodia apiculata tem distribuição neotropical (Andersson 1992), ocorrendo no México e nas Américas Central e do Sul (Bacigalupo \& Cabral 1999a; Lorence 1999). No Brasil, foi citada para as Regiões Nordeste e Sudeste (Barbosa et al. 1996; Jung-Mendaçolli 1999). Caracteriza-se por apresentar frutos com mericarpos indeiscentes. Em Guaribas, foi encontrada nas três áreas da unidade, principalmente nos tabuleiros, onde há bastante luminosidade e os solos são arenosos. Floresce e frutifica de março a novembro.

8. Mitracarpus frigidus var. discolor (Miq.) K. Schum., in Mart., Fl. bras. 6(6): 82. 1889.

Erva ereta, 30-70 cm alt., ramificada. Ramos hirsutos a híspidos. Estípulas 3-5×2-4 mm, unidas, fimbriadas, hirsutas, com 6-8 lacínios glandulares formando uma bainha. Folhas opostas. Lâmina foliar 2-5×0,5-1,5 cm, lanceolada, base atenuada, ápice agudo, cartácea, pubescente, hirsuta a híspida em ambas as faces, 3-4 pares de nervuras secundárias; pecíolo ausente. Glomérulos não capituliformes terminais e axilares, $0,5-1 \times 1-1,3 \mathrm{~cm}$, sésseis, (50-)120-180(-230) flores; 2-4 brácteas não involucrais, foliáceas, 1,5-4×0,5-1 cm, elípticas, verdes, hirsutas a 


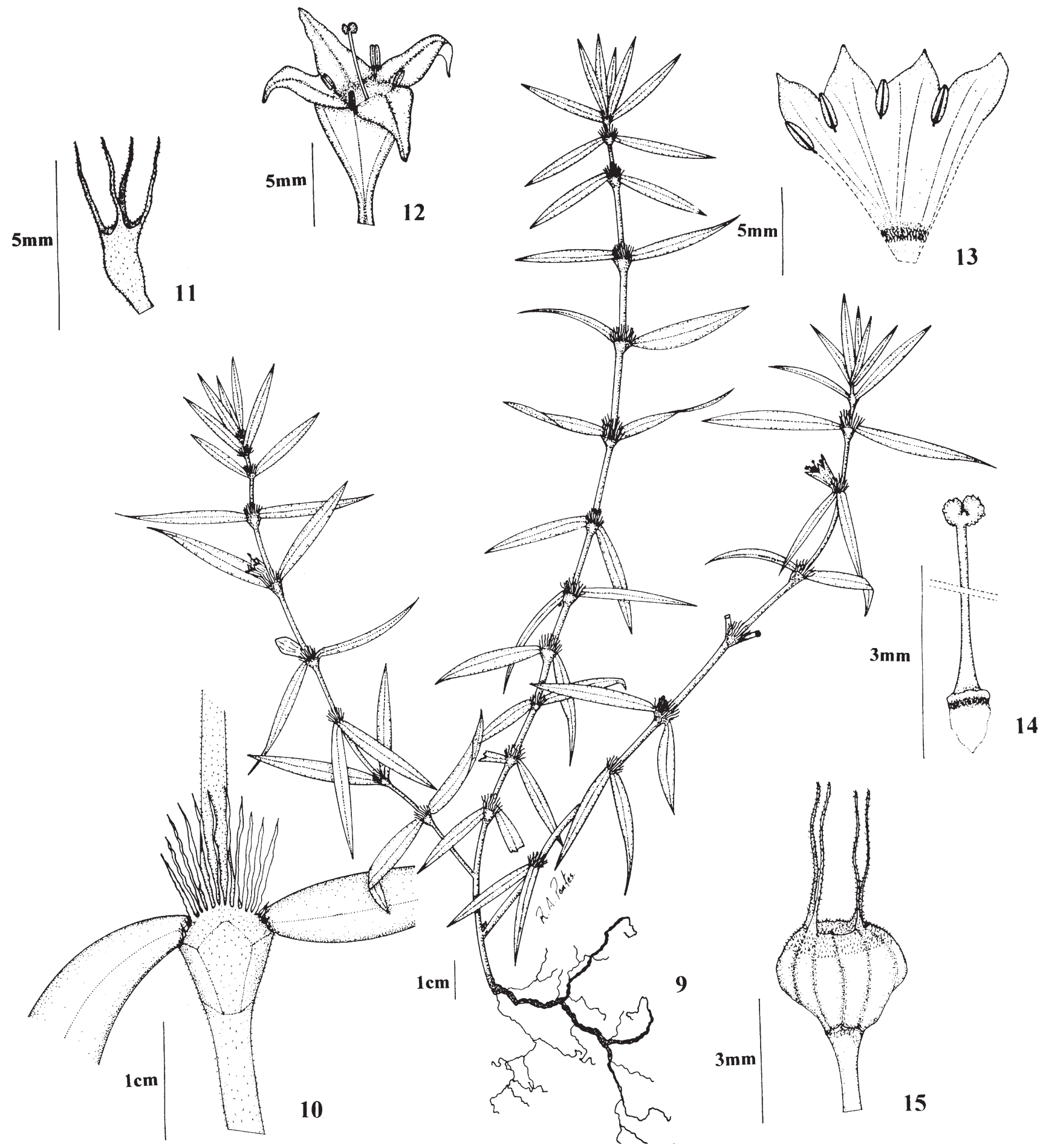

Figuras 9-15. Diodia apiculata (Willd. ex Roem. \& Schult.) K. Schum. 9. Hábito. 10. Estípula. 11. Cálice e ovário. 12. Corola-aspecto externo. 13. Corola-aspecto interno. 14. Estilete e estigma. 15. Fruto (Pereira 472). 
híspidas, 2 bractéolas florais, 1-2×1-1,5 mm, inconspícuas, verdes, glabras. Flores sésseis, botões florais oblongos, ápice agudo. Cálice subulado, 4-laciniado, 2-3×1-2 mm, hirsuto, lacínios desiguais entre si, dois a dois. Corola tubulosa, branca, tetrâmera, tubo 3-4×1,5-2 mm, pubérulo-papiloso externamente, internamente com um anel de tricomas no terço inferior, lobos 1-1,5×1-2 mm, triangulares, pilosos no ápice. Estames 4, inclusos, presos na porção mediana do tubo; anteras sésseis. Hipanto não muricado. Ovário bilocular, uniovulado, óvulos presos ao septo; estilete exserto, 3-5 mm compr., glabro; estigma bífido. Cápsula 1,5-2×0,5-0,8 mm, oblonga a oblongo-ovada, deiscência circuncisa, separando-se em duas partes, uma apical caduca, e outra basal persistente, glabra, pubérula a escabra. Sementes 0,5-1×0,5-1 mm, plano-convexas, oblongas, lisas na parte dorsal e com depressão em forma de Y na ventral.

Material selecionado: BRASIL. Paraíba: Mamanguape, Área II, 28/IX/2001, fl. fr., Pereira 600 (JPB).

Mitracarpus frigidus var. discolor tem distribuição neotropical (Andersson 1992). No Brasil, ocorre na Região Sudeste, no Estado do Espírito Santo, na Região Centro-Oeste, no Estado de Goiás e, na Região Nordeste, nos Estados de Pernambuco, Alagoas, Bahia, Ceará, Piauí e Paraíba (Schumann 1889; Souza 1997). Esta espécie tem preferência por ambientes litorâneos, como a Mata Atlântica e restingas. Caracteriza-se por apresentar frutos capsulares com deiscência circuncisa, lacínios do cálice desiguais, dois a dois. Em Guaribas, é comumente encontrada nas áreas de tabuleiros, ou na periferia da mata, onde a luminosidade é intensa. Floresce e frutifica de fevereiro a outubro.

9. Palicourea crocea (Sw.) Roem. \& Schult., Syst. Veg. 5: 193. 1819.

Fig. 16-19

Arbusto, 1-1,8 m alt. Ramos glabros. Estípulas 2-3×3-4 mm, livres, bipartidas, bífidas, híspidas. Folhas opostas. Lâmina foliar 10-15×3-4 cm, elíptica a lanceolada, base atenuada, ápice agudo a acuminado, membranácea, face superior híspida a escabra, face inferior híspida, 8-10 pares de nervuras secundárias; pecíolo 3-5×1-2 mm, híspido. Tirsos terminais, 4-8×3-6 cm, pedunculados, (7-)11-17(-25) flores; 2 brácteas não involucrais, inconspícuas, 3-4×1-2 mm, cônicas, verdes, híspidas, 1-2 bractéolas florais, 2-3×1-2 mm, cônicas, verdes, híspidas; pedúnculo 3-5,5 $\times 0,1-0,2 \mathrm{~cm}$, amarelo, alaranjado a avermelhado, híspido a hirsuto. Flores com pedicelo 3-4×1-2 mm, amarelo-esverdeado, híspido; botões florais oblongos, ápice obtuso. Cálice subulado, 5-laciniado, 2-4×2-3 mm, híspido, lacínios iguais entre si. Corola tubulosa, gibosa, amarela, pentâmera, tubo 1,5-2,5×0,2-0,4 cm, híspido externamente, internamente com um anel de tricomas na base, lobos 2-3×1-2 mm, triangulares, híspidos externamente e glabros internamente. Estames 5, inclusos, presos na porção superior do tubo; filetes 1-2 mm compr. Hipanto não muricado. Ovário bilocular, uniovulado, óvulos de inserção basal; estilete exserto, 2,5-2,8 cm compr., pubérulo-papiloso; estigma bífido. Drupa 4-5×5-6 mm, plano-convexa, costada, sulcada, amarela, alaranjada a avermelhada, glabra a pubérula, escabra; pirênios 3-4×3-3,5 mm, convexos, sulcados.

Material selecionado: BRASIL. Paraíba: Mamanguape, Área I, 23/III/2001, fl., Pereira 330 (JPB).

Palicourea crocea tem distribuição pantropical, sendo encontrada principalmente no México e nas Américas Central e do Sul (Steyermark 1974; Andersson 1992; Lorence 1999). No nordeste brasileiro, há registros desta espécie praticamente para todos os Estados (Zappi \& Stannard 1995; Barbosa et al. 1996). Diferencia-se das demais espécies estudadas pela corola de base gibosa, coloração amarela das flores, e frutos amarelo a avermelhados. Na REBIO Guaribas, é comum no sub-bosque da mata. Floresce de janeiro a maio e frutifica de maio a junho.

10. Psychotria bahiensis DC., Prodr. 4: 509. 1830.

Arbusto, 0,5-2 m alt. Ramos glabros. Estípulas 2-4×2-3 mm, livres, bipartidas, bífidas, glabras. Folhas opostas. Lâmina foliar 10-14×3-6cm, elíptica a lanceolada, base aguda a atenuada, ápice acuminado, cartácea, glabra em ambas as faces, 6-9 pares de nervuras secundárias; pecíolo 5-7×1-2 mm, glabro. Tirsos terminais, 3-6 $\times 2,5-4,5 \mathrm{~cm}$, pedunculados, (9)-16-26-(40) flores; 2 brácteas não involucrais, inconspícuas, 2-3×1-2 mm, triangulares, verdes, glabras, 1-2 bractéolas florais, 1-2×1-1,5 mm, triangulares, verdes, glabras; pedúnculo $2-4 \times 0,1-0,2 \mathrm{~cm}$, roxo a vinho, glabro a pubérulo. Flores sésseis, botões florais oblongos, ápice agudo a obtuso. Cálice campanulado, 5-denteado, 2-5×1-2 mm, glabro a pubérulo, dentes desiguais. Corola tubulosa, branca, pentâmera, tubo 3-4×2-3 mm, glabro externamente, internamente piloso do ponto de inserção dos estames até a fauce, lobos 1-2×1-1,5 mm, triangulares, glabros. Estames 5, exsertos, presos na porção mediana do tubo; filetes 1-2 mm compr. Hipanto não muricado. Ovário bilocular, 
uniovulado, óvulos de inserção basal; estilete exserto, 5-6 mm compr., glabro; estigma bífido a bilobado. Drupa 3-5×4-6 mm, globosa ou oblongo-ovada, costada, com sulcos longitudinais, branca, glabra; pirênios 3-4,5×3,5-5,5 mm, globosos, convexos, sulcados.

Material selecionado: BRASIL. Paraíba: Rio Tinto, Área III, 15/XI/2000, fl., Pereira 221 (JPB).

Psychotria bahiensis tem distribuição neotropical, ocorrendo na Colômbia, Equador, Peru, Venezuela, Guianas e Brasil (Steyermark 1974). Foi citada por Barbosa et al. (1996) e Pereira (1996) para o Nordeste brasileiro. Na REBIO Guaribas é amplamente distribuída no sub-bosque da mata. Floresce de janeiro a novembro e frutifica de abril a dezembro.

\section{Psychotria barbiflora DC., Prodr. 4: 509. 1830.}

Arbusto, 0,6-2 m alt. Ramos glabros. Estípulas 1-4×3-4 mm, livres, bipartidas, bífidas, glabras. Folhas opostas. Lâmina foliar 7-14×3-7 cm, elíptica a lanceolada, base aguda a atenuada, ápice acuminado, papirácea, glabra a pubérula em ambas as faces, 8-11 pares de nervuras secundárias; pecíolo $0,5-1 \times$ $0,1-0,2 \mathrm{~cm}$, glabro. Glomérulos capituliformes terminais, 1-1,8×1,5-2 cm, pedunculados, (6-)12-16(-25) flores; $12-15$ brácteas involucrais, rígidas, $0,7-1 \times 0,2-0,4 \mathrm{~cm}$, lineares, estreito-oblongas a estreito-lanceoladas, branco-esverdeadas a roxas, glabras; pedúnculo ereto quando jovem, 0,5-1×0,1-0,2 cm, verde, pubérulo. Flores sésseis, botões florais oblongos, ápice agudo a obtuso. Cálice truncado, 5-denteado, 0,5-1×0,2-0,5 mm, glabro, dentes desiguais. Corola tubulosa, branca, pentâmera, tubo 5-8 $\times 1-3 \mathrm{~mm}$, glabro externamente, internamente piloso do ponto de inserção dos estames até os lobos, lobos 1-2×1-1,5 mm, triangulares, glabros externamente e pilosos internamente. Estames 5, exsertos, presos na porção mediana do tubo; filetes $2-3 \mathrm{~mm}$ compr. Hipanto não muricado. Ovário bilocular, uniovulado, óvulos de inserção basal; estilete incluso, 4-5 mm compr., glabro; estigma bífido. Drupa 2-3×3-4 mm, globosa ou ovada, costada, com sulcos longitudinais, azul-escura, roxa a negra, glabra a escabra; pirênios 2-2,8 $\times 3-3,5 \mathrm{~mm}$, globosos ou ovados, convexos, sulcados.

Material selecionado: BRASIL. Paraíba: Mamanguape, Área II, 29/VI/2001, fl., Pereira 507 (JPB).

Psychotria barbiflora tem distribuição neotropical (Steyermark 1974; Andersson 1992; Lorence 1999), sendo encontrada no México e nas Américas Central e do Sul. No Brasil, habita matas de regiões litorâneas ou áreas de encostas. Foi citada por
Barbosa et al. (1996) e Pereira (1996) para o nordeste brasileiro e, para a Região Norte, por Campos et al. (1999). Segundo Steyermark (1972), no início da antese a inflorescência é compacta e monocéfala, porém, na pós-antese e nos frutos há uma gradual modificação deste caráter, com o desenvolvimento de eixos curtos. Psychotria barbiflora é muito semelhante a P. hoffmannseggiana (Willd. ex Roem. \& Schult.) Müll. Arg., diferenciando-se desta pelo hábito, pelo número e forma das brácteas que envolvem a inflorescência, e pelo direcionamento do pedúnculo. Na REBIO Guaribas ocorre no sub-bosque da mata, em lugares bastante sombreados. Floresce de fevereiro a junho e frutifica de dezembro a junho.

12. Psychotria bracteocardia (DC.) Müll. Arg., in Mart., Fl. bras. 6(5): 362. 1881.

Fig. 20-22

Arbusto ou subarbusto, 0,3-1 m alt. Ramos escabros. Estípulas 0,6-1×0,4-0,5 cm, livres, bipartidas, bífidas, escabras a híspidas. Folhas opostas. Lâmina foliar 15-24×4-7 cm, lanceolada, base atenuada, ápice agudo a acuminado, membranácea a papirácea, face superior glabra, face inferior escabra a híspida, 11-17 pares de nervuras secundárias; pecíolo $0,5-1,5 \times$ 0,1-0,2 cm, escabro. Glomérulos capituliformes terminais, 4-7,5×3-4 cm, pedunculados, (16-)25-42(-54) flores; 4 brácteas involucrais, $1-2,5 \times 0,5-2 \mathrm{~cm}$, largamente ovadas, roxas a purpúreas, escabras, 3-4 bractéolas florais, 5-8 $\times 3-5 \mathrm{~mm}$, oblongo-ovadas, roxas, escabras; pedúnculo 3-6×0,2-0,3 cm, roxo a vinho, hirsuto a híspido. Flores sésseis, botões florais oblongos, ápice agudo a obtuso. Cálice campanulado, 5-denteado, 2-3×1-2 mm, pubérulo, dentes desiguais. Corola tubulosa, roxa, pentâmera, tubo 6-9×2-2,5 mm, glabro externamente, internamente piloso do ponto de inserção dos estames até a fauce, lobos 1-2×1-1,5 mm, triangulares, pilosos no ápice. Estames 5, inclusos, presos na porção mediana do tubo; filetes 1-2 mm compr. Hipanto não muricado. Ovário bilocular, uniovulado, óvulos de inserção basal; estilete exserto, 0,7-1 cm compr., glabro; estigma bífido. Drupa 0,7-1,2×0,4-0,6 cm, oblonga ou ovada, costada, com sulcos longitudinais, azul a roxa, glabra; pirênios 0,7-1×0,3-0,5 cm, oblongos ou ovados, convexos, sulcados.

Material selecionado: BRASIL. Paraíba: Mamanguape, Área II, 31/V/2001, fl., Pereira 459 (JPB).

Psychotria bracteocardia tem distribuição neotropical, ocorrendo principalmente na América do 
Sul (Andersson 1992; Zappi \& Nunes 2000). No Brasil, ocorre nos Estados da Bahia, Ceará, Distrito Federal, Goiás, Pará, Paraíba, Piauí, Rio de Janeiro, Roraima e Tocantins (Müller 1881; Zappi \& Nunes 2000). Caracteriza-se por apresentar inflorescências envolvidas por brácteas grandes e vistosas, de coloração roxa a purpúrea, e lâminas foliares lanceoladas. Em Guaribas, é freqüente no sub-bosque da mata. Floresce de fevereiro a maio e frutifica de maio a dezembro.

13. Psychotria carthagenensis Jacq., Enum. Syst. Pl. Carib. 16. 1760.

Arvoreta ou arbusto, 2-4 m alt. Ramos glabros. Estípulas 0,7-2×0,5-1 cm, livres, inteiras, obovadas, glabras. Folhas opostas. Lâmina foliar $15-26 \times 6-11 \mathrm{~cm}$, elíptica a largamente lanceolada, base atenuada, ápice acuminado, subcoriácea, glabra em ambas as faces, 6-9 pares de nervuras secundárias; pecíolo 2-3x $0,2-0,3 \mathrm{~cm}$, glabro. Panículas densifloras terminais, 9-16×6-8cm, pedunculadas, (32-)70-85(-123) flores; 2 brácteas não involucrais, inconspícuas, 2-5×1-3 mm, triangulares, branco-esverdeadas, glabras; pedúnculo 7-13×0,3-0,4 cm, verde, glabro. Flores com pedicelo 2-3×1-1,5 mm, escabro, botões florais oblongos, ápice agudo a obtuso. Cálice subtruncado a denteado, 5-denteado, 1-2×1-1,5 mm, pubérulo, dentes desiguais. Corola infundibuliforme a tubulosa, branca, pentâmera, tubo 4-5×2-3 mm, glabro externamente, internamente piloso do ponto de inserção dos estames até a fauce, lobos 2-3×1-2 mm, triangulares, glabros. Estames 5, exsertos, presos na porção mediana do tubo; filetes 2-3 mm compr. Hipanto não muricado. Ovário bilocular, uniovulado, óvulos de inserção basal; estilete exserto, 6-7 mm compr., glabro; estigma bífido. Drupa 3-4x 3-4 mm, globosa ou oblongo-ovada, costada, com sulcos longitudinais, alaranjada a avermelhada, glabra; pirênios 2,8-4×3-3,8 mm, globosos ou oblongos, convexos, sulcados.

Material selecionado: BRASIL. Paraíba: Mamanguape, Área II, 23/X/2000, fr., Pereira 201 (JPB).

Psychotria carthagenensis possui ampla distribuição na região neotropical (Steyermark 1972; Andersson 1992; Lorence 1999). No Brasil, ocorre no Estado do Amazonas, na Região Nordeste, no Distrito Federal, no Estado de São Paulo e na Região Sul (Zappi \& Stannard 1995; Barbosa et al. 1996; Zappi \& Nunes 2000). Caracteriza-se por apresentar estípulas terminais obovadas, com ápice obtuso, rompendo-se após o desenvolvimento da gema foliar, inflorescências não envolvidas por brácteas involucrais, e pedúnculo longo. Em Guaribas, é encontrada apenas no interior da mata. Floresce de maio a novembro e frutifica de setembro a novembro.

14. Psychotria hoffmannseggiana (Willd. ex Roem. \& Schult.) Müll. Arg., in Mart., Fl. bras. 6(5): 336. 1881 .

Subarbusto, 30-60 cm alt. Ramos glabros. Estípulas 2-4×2-2,5 mm, livres, bipartidas, bífidas, glabras. Folhas opostas. Lâmina foliar $6-8 \times 2-3 \mathrm{~cm}$, elíptica a lanceolada, base atenuada, ápice acuminado, membranácea, glabra em ambas as faces, 6-7 pares de nervuras secundárias; pecíolo 2-3×1-1,5 mm, glabro. Glomérulos capituliformes terminais, $0,7-1,2 \times 1-1,5 \mathrm{~cm}$, pedunculados, (7-)11-15(-17) flores; 4 brácteas involucrais, rígidas, $3-6 \times 2-3 \mathrm{~mm}$, ovadas a estreitoovadas, branco-esverdeadas, rosadas a roxas, glabras; pedúnculo pêndulo quando jovem, 4-8×1-2 mm, esverdeado a roxo, pubérulo a escabro. Flores sésseis, botões florais arredondados, ápice obtuso a circular. Cálice truncado, 5-denteado, 1-1,5×1-2 mm, glabro, dentes desiguais. Corola infundibuliforme, branca, pentâmera, tubo 4-5×2-2,5 mm, glabro externamente, internamente piloso do ponto de inserção dos estames até os lobos, lobos 1-1,5×1-2 mm, triangulares, pilosos no ápice. Estames 5, exsertos, presos na porção mediana do tubo; filetes $0,5-1 \mathrm{~mm}$ compr. Hipanto não muricado. Ovário bilocular, uniovulado, óvulos de inserção basal; estilete exserto, 3-4 mm compr., glabro; estigma bífido. Drupa 1,5-2,5×2,5-3 mm, globosa ou ovada, costada, com sulcos longitudinais, azul, roxa a negra, glabra; pirênios 1,5-2×2-3 mm, globosos ou ovados, convexos, sulcados.

Material selecionado: BRASIL. Paraíba: Mamanguape, Área II, 23/II/2001, fl., Pereira 285 (JPB).

Psychotria hoffmannseggiana tem distribuição neotropical, ocorrendo no México e nas Américas Central e do Sul (Müller 1881; Steyermark 1974; Andersson 1992; Lorence 1999). É bem distribuída nas diversas regiões brasileiras e, na Região Nordeste, é encontrada em remanescentes de Mata Atlântica, brejos de altitude e restingas arbóreas (Barbosa et al. 1996). Caracteriza-se pelo porte subarbustivo e inflorescências com pedúnculo pêndulo quando jovem. Em Guaribas, ocorre frequientemente no subbosque da mata, em lugares bastante sombreados, formando verdadeiros tapetes no interior da mata. Floresce de fevereiro a junho e frutifica de junho a novembro. 
15. Psychotria subtriflora Müll. Arg., Flora 59: 553. 1876.

Arbusto, 0,6-2,5 $\mathrm{m}$ alt. Ramos glabros. Estípulas 1-2×1,5-2 mm, livres, inteiras, truncadas, glabras. Folhas opostas. Lâmina foliar 2-4×1-1,5 cm, elíptica a lanceolada, base atenuada, ápice agudo, membranácea, glabra em ambas as faces, 4-6 pares de nervuras secundárias; pecíolo 2-3×0,5-1 mm, glabro. Cimeiras terminais ou axilares, $5-7 \times 4-8 \mathrm{~mm}$, pedunculadas, (1-)2-3(-4) flores; brácteas ausentes; pedúnculo 2-3×1-2 mm, branco-esverdeado, glabro. Flores sésseis, botões florais oblongos, ápice agudo a acuminado. Cálice truncado a campanulado, 5-denteado, 1-1,5×1-2 mm, glabro, dentes desiguais. Corola infundibuliforme, branca, pentâmera, tubo 2-3×1-2 mm, glabro externamente, internamente com um anel de tricomas apenas no ponto de inserção dos estames, lobos 4-5×1-2 mm, oblongos, pilosos no ápice. Estames 5 , inclusos, presos na porção mediana do tubo; filetes 0,1-0,2 mm compr. Hipanto não muricado. Ovário bilocular, uniovulado, óvulos de inserção basal; estilete exserto, 6-8 mm compr., glabro; estigma bífido. Drupa 4-6×3-5 mm, esférica, ovada ou oblongo-ovada, costada, com sulcos longitudinais, vermelha, glabra; pirênios 3,5-5,5×3-4,5 mm, esféricos, ovados ou oblongo-ovados, convexos, sulcados.

Material selecionado: BRASIL. Paraíba: Mamanguape, Área I, 13/XII/2000, fl., Pereira 230 (JPB).

Psychotria subtriflora tem distribuição neotropical, ocorrendo nos campos rupestres das Regiões Nordeste e Sudeste do Brasil, e provavelmente nas restingas do Estado do Rio de Janeiro, e no Paraguai (Zappi \& Nunes 2000). No Estado da Paraíba, foi registrada anteriormente em áreas de restinga arbórea por Pontes (dados não publicados), e em tabuleiros no município de Sapé, por Dionisio (dados não publicados). Diferencia-se das demais espécies de Psychotria estudadas por apresentar inflorescências desprovidas de brácteas e estípulas truncadas. Em Guaribas, é comum no tabuleiro ou nas áreas de transição matatabuleiro. Foi encontrada com flores em março, junho, julho e dezembro e com frutos em janeiro, março, maio, junho e novembro.

16. Richardia grandiflora (Cham. \& Schltdl.) Steud., Nomencl. Bot. 2: 459. 1841.

Fig. 23-26

Erva prostrada, às vezes ereta, 20-60 cm alt., ramificada. Ramos flexuosos, hirsutos. Estípulas
4-6×3-5 mm, unidas, fimbriadas, hirsutas, com 6-8 lacínios ciliados formando uma bainha. Folhas opostas. Lâmina foliar 2-5×0,5-2 cm, lanceolada, base atenuada, ápice agudo, membranácea, escabra a híspida em ambas as faces, 2-3 pares de nervuras secundárias; pecíolo 4-5×1-2 mm, hirsuto. Glomérulos capituliformes terminais, 0,7-1,5×0,8-1,4 cm, sésseis, (6-)8-12(-16) flores; 4 brácteas involucrais, foliáceas, $1-2,5 \times 0,5-1 \mathrm{~cm}$, ovadas, verdes, escabras a híspidas, 4 bractéolas florais, 2-3×1-2 mm, lineares, verdes, glabras. Flores sésseis, botões florais arredondados, ápice obtuso a circular. Cálice subulado, 6-laciniado, 4-5×1-2 mm, híspido a escabro, lacínios iguais entre si. Corola infundibuliforme, lilás, hexâmera, tubo $0,7-1 \times 0,2-0,3 \mathrm{~cm}$, glabro externamente, internamente com um anel de tricomas no terço inferior ou na base, lobos 1-3×1-2 mm, triangulares, pilosos no ápice. Estames 6, exsertos, presos na fauce; filetes 1-2 mm compr. Hipanto muricado. Ovário trilocular, uniovulado, óvulos presos ao septo; estilete exserto, 0,9-1,2 cm compr., glabro; estigma trífido. Esquizocarpo 1,2-1,5×1-1,2 mm, oblongo a oblongo-elíptico, muricado, três mericarpos indeiscentes, glabro. Sementes 0,5-1×0,5-1,2 mm, planoconvexas, semi-cilíndricas, muricadas.

Material selecionado: BRASIL. Paraíba: Rio Tinto, Área III, 15/XI/2000, fl. fr., Pereira 215 (JPB).

Richardia grandiflora tem distribuição neotropical (Andersson 1992). No Brasil, é uma espécie freqüente em todas as regiões. Caracteriza-se por apresentar glomérulos capituliformes terminais, com brácteas involucrais, corola hexâmera, ovário trilocular, estigma trífido e frutos separando-se em três mericarpos indeiscentes. Em Guaribas, é freqüente em lugares com vegetação de porte arbustivo-herbáceo, solos arenosos com intensa luminosidade, ou ainda nas bordas da mata. Floresce e frutifica de março a novembro.

17. Staelia virgata (Roem. \& Schult.) K. Schum., in Mart., Fl. bras. 6(6): 76. 1889.

Fig. 27-29

Erva ereta, 30-60 cm alt., ramificada. Ramos pubérulos a escabros. Estípulas 2-5×2-4 mm, unidas, fimbriadas, pubérulas a escabras, com 5-8 lacínios glandulares formando uma bainha. Folhas opostas. Lâmina foliar 2,5-4,5×0,3-0,6 cm, linear-lanceolada, base atenuada, ápice agudo, margem revoluta, membranácea, face superior glabra, face inferior esparsamente escabra, 2-3 pares de nervuras secundárias; pecíolo ausente. Glomérulos não capituliformes axilares, raramente terminais, 

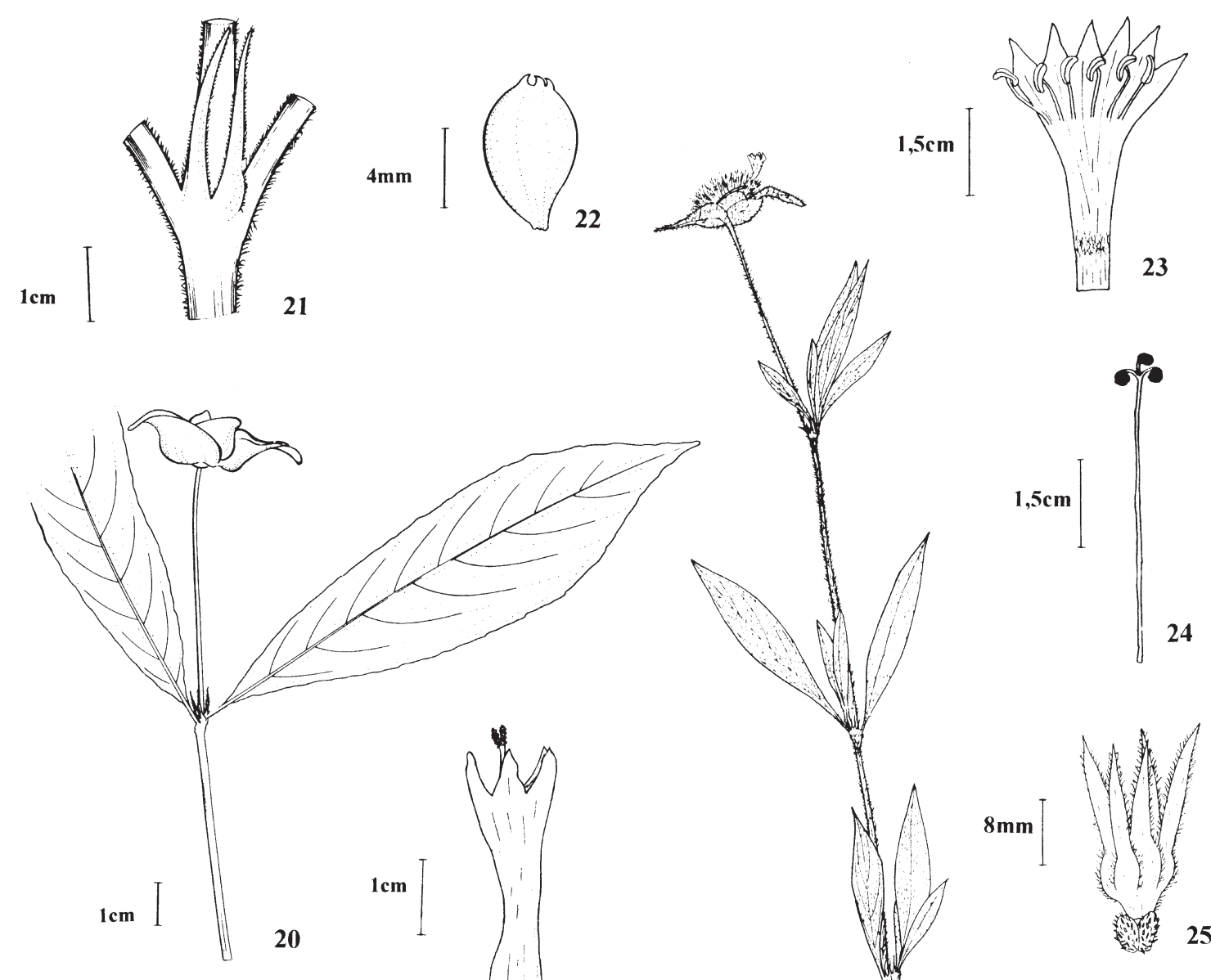
0,5-1,2×1-1,7 cm, sésseis, (10-)12-20(-32) flores; 2-3 brácteas não involucrais, foliáceas, $1,5-4 \times 0,3-0,5 \mathrm{~cm}$, linear-lanceoladas, verdes, escabras, 2 bractéolas florais 1-2×0,5-1 mm, lineares, verdes, glabras. Flores sésseis, botões florais oblongos, ápice obtuso. Cálice subulado, 2-laciniado, 2-4×1-2 $\mathrm{mm}$, pubérulo a escabro, lacínios iguais entre si. Corola infundibuliforme a tubulosa, branca, tetrâmera, tubo 4-6×1-2 mm, pubérulo externamente, internamente com um anel de tricomas no terço inferior, lobos 1-2×1-1,5 mm, triangulares, pubescentes no ápice. Estames 4, exsertos, presos na fauce; filetes 1-2,2 mm compr. Hipanto não muricado. Ovário bilocular, uniovulado, óvulos presos ao septo; estilete exserto, 5-8 mm compr., glabro; estigma bífido. Cápsula 1-1,5×1-1,2 mm, oblonga a obovada, deiscência transverso-oblíqua, separando-se em duas porções independentes, coroadas pela sépala correspondente, escabra. Sementes 1-1,2×0,5-0,7 mm, planas, convexas, semi-cilíndricas, com sulcos ao redor do estrofíolo.

Material examinado: BRASIL. Paraíba: Mamanguape, Área I, 29/VII/2001, fl. fr., Pereira 521 (JPB).

Staelia virgata tem distribuição neotropical, abrangendo parte do território do Peru, Paraguai até o norte da Argentina (Andersson 1992). No Brasil, ocorre nos Estados do Amazonas, Pará, Tocantins, Minas Gerais, Pernambuco, Bahia, Ceará, Maranhão, Paraíba, Rio Grande do Norte e Piauí, até a Região Sul (Schumann 1889; Souza 1997; Souza \& Sales 2004). Caracteriza-se pelos frutos capsulares, com deiscência transverso-oblíqua, e cálice com lacínios iguais entre si. Em Guaribas, é freqüentemente encontrada nas áreas onde há solo arenoso, bastante luminosidade e vegetação arbustivo-herbácea, ou ainda na borda da mata. Floresce e frutifica de fevereiro a novembro.

18. Perama hirsuta Aubl., Hist. Pl. Gui. Franç. 1: 54. 1775.

Erva ereta, $10-30 \mathrm{~cm}$ alt. Ramos hirsutos. Estípulas 0,2-0,3×0,5-1 mm, livres, inteiras, truncadas, hirsutas. Folhas opostas. Lâmina foliar 0,7-1×0,3-0,4 cm, ovada a lanceolado-ovada, base obtusa, ápice agudo, membranácea, hirsuta em ambas as faces, 2-3 pares de nervuras secundárias; pecíolo ausente. Racemos espiciformes terminais ou axilares, $1,5-3 \times 0,5-0,7 \mathrm{~cm}$, pedunculados, (15-)20-30(-40) flores; 2 brácteas não involucrais, foliáceas, 5-6×1-2 mm, lanceolado-ovadas, verdes, hirsutas; pedúnculo 1-2,5×0,1-0,2 cm, amareloesverdeado, hirsuto. Flores sésseis, botões florais oblongos, ápice agudo. Cálice subulado, 2-laciniado, 3-4×1-2 mm, hirsuto, lacínios pinatissectos. Corola infundibuliforme, amarela, tetrâmera, tubo 2-2,5×0,5-1 mm, glabro externamente, internamente com um anel de tricomas no ponto de inserção dos estames, lobos 0,5-1×0,3-0,5 mm, triangulares, pilosos no ápice. Estames 4, exsertos, presos na fauce; filetes 0,1-0,2 mm compr. Hipanto não muricado. Ovário trilocular, uniovulado, óvulos presos ao septo na porção mediana; estilete exserto, 3-3,5 mm compr., glabro; estigma bífido. Cápsula 2-3×1-2 mm, subglobosa, deiscência transversal, circuncisa, parte basal fixa, persistente, amarelo-esverdeada, hirsuta. Sementes 0,3-0,5×0,2-0,5 mm, piramidais, cônicas, semicilíndricas, muricadas.

Material selecionado: BRASIL. Paraíba: Mamanguape, Área II, 28/IX/2001, fl. fr., Pereira 596 (JPB).

Perama hirsuta tem distribuição neotropical (Andersson 1992), na Venezuela, Guianas, Suriname, Guiana Francesa e Brasil (Steyermark 1974). No Brasil, há registros para os Estados do Amazonas, Pará, Piauí, Goiás e Bahia (Schumann 1888). Na REBIO Guaribas, ocorre apenas em lugares de solos arenosos e bastante úmidos. Encontrada com flores e frutos em março, junho, setembro, outubro e dezembro.

\section{Agradecimentos}

Agradecemos ao CNPq, pela concessão de bolsas às autoras; aos funcionários da REBIO Guaribas, IBAMA/PB, ao Dr. Wm. Wayt Thomas, pela revisão do Abstract, e às Dras. Ariane Luna Peixoto e Maria de Fátima Agra, pela revisão criteriosa do manuscrito original.

\section{Referências bibliográficas}

Andersson, L. 1992. A provisional checklist of neotropical Rubiaceae. Scripta Botanica Belgica 1: 1-199.

Andersson, L. \& Rova, J.H.E. 1999. The rps16 intron and the phylogeny of the Rubioideae (Rubiaceae). Plant Systematics and Evolution 214: 161-186.

Bacigalupo, N.M. \& Cabral, E.L. 1996. Infrageneric classification of Borreria (Rubiaceae-Spermacoceae) on the basis of American species. Opera Botanica Belgica 7: 297-308.

Bacigalupo, N.M. \& Cabral, E.L. 1998. Nota sobre dos especies de Borreria (Rubiaceae-Spermacoceae). Hickenia 2(56): 261-267.

Bacigalupo, N.M. \& Cabral, E.L. 1999a. Revisión de las especies americanas del género Diodia (Rubiaceae, Spermacoceae). Darwiniana 37(1-2): 153-165.

Bacigalupo, N.M. \& Cabral, E.L. 1999b. Sobre da identidad de dos especies de Lamarck, Spermacoce laevis y $S$. remota (Rubiaceae, Spermacoceae). Darwiniana 37(3-4): 333-334. 
Barbosa, M.R.V.; Mayo, S.J.; Castro, A.A.J.F.; Freitas, G.L.; Pereira, M.S.; Gadelha, N.P.C. \& Moreira, H.M. 1996. Checklist preliminar das angiospermas. In: E.V.S.B. Sampaio; S.J. Mayo \& M.R.V. Barbosa (eds.). Pesquisa botânica nordestina: progresso e perspectivas. Recife, Sociedade Botânica do Brasil, Seção Regional de Pernambuco.

Barroso, G.M.; Guimarães, E.F.; Ichaso, C.L.F.; Costa, C.G.; Peixoto, A.L. \& Lima, H.C. 1986. Sistemática de angiospermas do Brasil. v.3. Viçosa, Universidade Federal de Viçosa.

Barroso, G.M.; Morim, M.P.; Peixoto, A.L. \& Ichaso, C.L.F. 1999. Frutos e sementes: morfologia aplicada à sistemática de dicotiledôneas. Viçosa, Universidade Federal de Viçosa.

Bremer, B. \& Manen, J.F. 2000. Phylogeny and classification of the subfamily Rubioideae (Rubiaceae). Plant Systematics and Evolution 225: 43-72.

Brummitt, R.K. \& Powell, C.E. 1992. Authors of plant names. Kew, Royal Botanic Gardens.

Burger, W. \& Jiménez, Q. 1994. A new species of Psychotria subgenus Psychotria (Rubiaceae) from Costa Rica. Novon 4: 206-208.

Cabral, E.L. 1996. Cuatro especies nuevas de Borreria (Rubiaceae) para la flora de Brasil. Bonplandia 9(1-2): 35-41.

Cabral, E.L. 1999. Borreria delicatula, un nuevo nombre en Rubiaceae. Hickenia 3(7): 21.

Cabral, E.L. \& Bacigalupo, N.M. 1996. Revision of Borreria section Pseudodiodia (Rubiaceae, Spermacoceae). Opera Botanica Belgica 7: 309-327.

Cabral, E.L. \& Bacigalupo, N.M. 1999. Estudio de las especies americanas de Borreria series Laeves (Rubiaceae, Spermacoceae). Darwiniana 37(3-4): 259-277.

Cabral, E.L. \& Bacigalupo, N.M. 2000a. Novedades en Rubiaceae-Spermacoceae de la flora de São Paulo, Brasil. Boletin de la Sociedad Argentina de Botanica 34(3-4): 149-155.

Cabral, E.L. \& Bacigalupo, N.M. 2000b. Novedades taxonómicas en Galianthe y Borreria (Rubiaceae, Spermacoceae). Bonplandia 10(1-4): 119-128.

Campos, M.T.V.A.; Brito, J.M. \& Taylor, C.M. 1999. Rubiaceae. Pp. 625-647. In: J.E.L. Ribeiro; M.J.G. Hopkins; A.Vicentini; C.A. Sothers; M.A.S. Costa; J.M. Brito; M.A.D. Souza; L.H.P. Martins; L.G. Lohmann; P.A.C.L Assunção; E.C. Pereira; C.F. Silva; M.R. Mesquita \& L.C. Procópio (eds.). Flora da Reserva Ducke. Guia de identificação das plantas vasculares de uma floresta de terra-firme na Amazônia Central. Manaus, INPA.

Delprete, P.G. 2001. Notes on some South American species of Psychotria subgenus Heteropsychotria (Rubiaceae), with observations on rubiaceous taxonomic characters. Brittonia 53(3): 396-404.

Dillenburg, C.R. \& Porto, M.L. 1985. Rubiaceae tribo Psychotrieae. Flora Ilustrada do Rio Grande do Sul. Fasc. XVI. Boletim do Instituto de Biociências 39: 1-76.

Figueiredo, M.A.; Fernandes, A.; Diógenes, M.B. \& Oliveira, S.S. 1990. A família Rubiaceae na Serra de Baturité, Ceará. Coleção Mossoroense (749).
Hamilton, C.W. 1989. A revision of mesoamerican Psychotria subgenus Psychotria (Rubiaceae), part I: introduction and species 1-16. Annals of the Missouri Botanical Garden 76: 67-111.

Holmgren, P.K.; Holmgren, N.H. \& Barnett, L.C. 1990. Index Herbariorum. The Herbaria of the World. Regnum Vegetabilium 120. Part I. Ed. 8. New York, New York Botanical Garden, Bronx.

Johansson, J.T. 1992. Pollen morphology in Psychotria (Rubiaceae, Rubioideae, Psychotrieae) and its taxonomic significance. A preliminary survey. Opera Botanica 115: $1-71$.

Jung-Mendaçolli, S.L. 1994. Flora fanerogâmica da Reserva do Parque Estadual das Fontes do Ipiranga (São Paulo, Brasil) Rubiaceae. Hoehnea 21(1/2): 97-129.

Jung-Mendaçolli, S.L. 1999. Flora fanerogâmica da Ilha do Cardoso (São Paulo, Brasil) Rubiaceae. Pp. 45-136. In: M.M.R.F. Melo (ed.). Flora Fanerogâmica da Ilha do Cardoso. v.6. São Paulo, Instituto de Botânica.

Kirkbride, J.H.Jr. 1976. A revision of the genus Declieuxia (Rubiaceae). Memoirs of the New York Botanical Garden 28(4): 1-87.

Lorence, D.H. 1999. A nomenclator of Mexican and Central American Rubiaceae. St. Louis, Missouri Botanical Garden Press.

Müller A.J. 1881. Rubiaceae. In: C.F.P. Martius (ed.). Flora Brasiliensis 6(5): 1-470.

Pereira, M.S. \& Barbosa, M.R.V. 2004. A família Rubiaceae na Reserva Biológica Guaribas, Paraíba, Brasil. Subfamílias Antirheoideae, Cinchonoideae e Ixoroideae. Acta Botanica Brasilica 18(2): 305-318.

Porto, M.L.; Jacques, S.M.C.; Miotto, S.T.S.; Waechter, J.L. \& Detoni, M.L. 1977. Tribo Spermacoceae-Rubiaceae I. Flora Ilustrada do Rio Grande do Sul. Fasc. XII. Boletim do Instituto de Biociências 35: 1-114.

Rizzini, C.T. 1977. Sistemática terminológica da folha. Rodriguésia 29(42): 103-125.

Robbrecht, E. 1988. Tropical woody Rubiaceae. Opera Botanica Belgica 1: 1-271.

Rova, J.H.E.; Delprete, P.G.; Andersson, L. \& Albert, V.A. 2002. A trnL-F cpDNA sequence study of the Condamineeae-Rondeletieae-Sipaneeae complex with implications on the phylogeny of the Rubiaceae. American Journal of Botany 89(1): 145-159.

Schumann, K. 1888. Rubiaceae. In: C.F.P. Martius (ed.). Flora Brasiliensis 6(6): 1-123.

Schumann, K. 1889. Rubiaceae. In: C.F.P. Martius (ed.). Flora Brasiliensis 6(6): 124-466.

Smith, L.B. \& Downs, R.J. 1956. Resumo preliminar das Rubiáceas de Santa Catarina. Sellowia 7: 13-86.

Souza, E.B. 1997. Estudos taxonômicos dos gêneros Staelia Cham. \& Schltdl. e Mitracarpus Zucc. ex Roem. \& Schult. (Spermacoceae - Rubiaceae) no Estado de Pernambuco - Brasil. Dissertação de Mestrado. Recife, Universidade Federal Rural de Pernambuco.

Souza, E.B. \& Sales, M.F. 2001. Mitracarpus longicalyx (Rubiaceae, Spermacoceae), a new species from northeastern Brazil. Brittonia 53(4): 482-486. 
Souza, E.B. \& Sales, M.F. 2004. O gênero Staelia Cham. \& Schltdl. (Rubiaceae - Spermacoceae) no Estado de Pernambuco, Brasil. Acta Botanica Brasilica 18(4): 919-926.

Steyermark, J.A. 1972. Rubiaceae. In: J.A. Steyermark \& B. Maguire (eds.). The Botany of the Guayana Highland, Part. IX. Memoirs of the New York Botanical Garden 23: $227-832$.

Steyermark, J.A. 1974. Rubiaceae. In: T. Lasser (ed.). Flora de Venezuela: primeira parte 9: 1-593; secunda parte 9: 603-1101; tercera parte 9: 1111-2070.

Sucre, D. 1959. Rubiaceae da cidade do Rio de Janeiro I, Tribo Spermacoceae. Rodriguésia 33: 241-280.

Sucre, D. 1960/1961. Estudo das Rubiaceae brasileiras I. Rodriguésia 35: 11-20.

Sucre, D. 1971. Estudos das Rubiaceae brasileiras III, cinco novas espécies da tribo Spermacoceae. Rodriguésia 38: 253-260.

Taylor, C.M. 1994a. Three new species of Psychotria subg. Heteropsychotria (Rubiaceae) from Western Amazonia. Novon 4: 174-178.
Taylor, C.M. 1994b. Taxonomic notes on Psychotria (Rubiaceae) in Western South America. Novon 4: 303-306.

Taylor, C.M. 1994c. Revision of Hillia (Rubiaceae). Annals of The Missouri Botanical Garden 81: 571-609.

Taylor, C.M. 1997. Conspectus of the genus Palicourea (Rubiaceae: Psychotrieae) with the description of some new species from Ecuador and Colombia. Annals of The Missouri Botanical Garden 84: 224-262.

Taylor, C.M. 2000. New species and a new name in Palicourea (Rubiaceae: Psychotrieae) from Northwestern South America. Novon 10: 78-87.

Taylor, C.M. \& Lorence, D.H. 1992. Notes on Psychotria subgenus Heteropsychotria (Rubiaceae: Psychotrieae) in Mexico and Northern Central America. Novon 2: 259-266.

Verdcourt, B. 1958. Remarks on the classification of the Rubiaceae. Bulletin du Jardin Botanique de l'État Bruxelles 28: 209-290.

Zappi, D.C. \& Nunes, T.S. 2000. Notes on the Rubiaceae of Northeastern Brazil. I. Erithalis, Psychotria and Rudgea. Kew Bulletin 55: 655-668.

Zappi, D.C. \& Stannard, B.L. 1995. Rubiaceae. In: B.L. Stannard (ed.). Flora of the Pico das Almas, Chapada Diamantina, Bahia, Brazil. Kew, Royal Botanic Gardens. 